\title{
POLLUTION OF RAW AND PASTEURIZED MILK WITH SOME HEAVY METALS
}

Al-Ganzoury, H.H. and El-Shorbagy I.M. Animal Health Research Institute (Zagazig Branch)

\begin{abstract}
The present work was conducted to determine the levels of some heavy metals as cadmium, lead, copper and zinc in milk. A total of 100 samples of farm bulk milk (30), market raw milk (30) and pasteurized milk (40) were examined using Atomic Absorption Spectrophotometer. Results of chemical analysis of farm bulk milk revealed that the mean levels of the examined metals were $0.299 \pm 0.016,2.375 \pm 0.013,2.120 \pm 0.030$ and $5.750 \pm 0.012$ ppm., respectively. With regard to market raw milk the mean levels were $0.241 \pm 0.037,2.076 \pm 0.163,0.103 \pm 0.006$ and $3.844 \pm 0.088$ ppm., respectively. Concerning pasteurized milk, the mean levels were $0.17 \pm 0.002,4.53 \pm 0.49,1.69 \pm 0.051$ and $3.37 \pm 0.012$ ppm., respectively. According to the permissible limits of abroad the results indicated that 100\%, 96.6\% and 90\% of farm bulk milk, market raw milk and pasteurized milk samples respectively contained cadmium, 100\%, 100\% and 95\% respectively contained lead, 93.3, 93.3 and 95 respectively contained copper and 96.6,93.3 and 98.3 respectively contained zinc beyond the maximum permissible limits for human consumption. The results of statistical analysis of examined heavy metals revealed that there is a significant difference between the farm bulk milk and market raw milk as well as market raw milk and pasteurized milk. The public health significance and suggested precautions for minimizing the levels of such metals were discussed.
\end{abstract}




\section{INTRODUCTION}

Environmental pollution with heavy metals led to a growing awareness of the potential hazards of heavy metal contamination in milk, water and feed stuffs which represent an important part of man and animal diet (Crossman, 1981). Heavy metals are among the chemical contaminants which have a major risk to animal and human health when present at higher concentrations but it known to be essential to human and animals life at low concentrations (Crosby, 1977).

The toxic elements, which are considered of major interest in food safety include lead, cadmium and zinc. Zinc is recognized as nutrient and cadmium has no essential biological value but there are some suggestions that arsenic and lead might be nutritionally essential (Mahaffey, 1977).

Contamination of milk starts at the farm and continue throughout the processing and distribution chain to storage and final preparation by the consumer or food service industry. So, good Manufacturing Practice (GMP) including processing, distribution and marketing are essential to ensure consumer protection $(\boldsymbol{F A O}, 1992)$.

The toxic effects include central nervous system damage, permanent mental retardation in children, kidney diseases, acute gastroenteritis,acute pulmonary edema and possibly carcinogenesis( $\mathbf{C a r l}$, 1991 and Skibniewska, 2002). The general adverse toxic effects are cumulative especially in adipose tissue. Other effects include offflavours in food when present at high concentrations (Bluhean et al. 1984 and Antoniou et al. 1989).

In developing countries the problems regarding the unhealthy environment, bad sanitation and problems of poor environment have a negative and direct impact on the health.

Therefore, the present work aims to monitor the levels of some heavy metals in raw and pasteurized milk to ensure the availability of milk for consumption. 


\section{MATERIAL \& METHODS}

\section{Collection of samples}

A total of 100 samples of farm bulk milk (30), market raw milk (30) and pasteurized milk (40) were collected from Sharkia Governorate. The farm samples were collected weekly for 30 weeks from ten dairy cow's farm in capped polypropylene containers and preserved at-20 ${ }^{\circ} \mathrm{C}$ till analysis. Market raw milk samples and pasteurized milk samples were collected from different shopping sites of the same Governorate to be analyzed chemically.

\section{Analysis of heavy metals}

The extraction of heavy metals from milk was carried out according to Hankinson(1975). In $250 \mathrm{ml}$ capacity Erlenmeyer flask,equal volumes (50 ml each) of milk and tricholoroacetic acid (20\%) were mixed by shaking frequently every 5 minutes for 30 minutes before being filtered through a $0.45 \mu \mathrm{n}$ membrane filter, lead, cadmium, copper and zinc in filtered samples were quantitatively detected using Atomic Absorption Spectrophotometer.

\section{RESULTS}

Table (1): Levels of heavy metals (ppm) in farm bulk milk, market raw milk and pasteurized milk

\begin{tabular}{||c||c||c|c|c|c||}
\hline \multirow{2}{*}{ Type of samples } & \multirow{2}{*}{ Levels } & \multicolumn{4}{c||}{ Heavy metals } \\
\cline { 3 - 6 } & & Cadmium & Lead & Copper & Zinc \\
\hline \hline \multirow{3}{*}{ Farm bulk milk } & -Minimum & 0.027 & 0.015 & 0.274 & 1.921 \\
& -Maximum & 0.539 & 3.827 & 5.983 & 11.869 \\
& -Mean \pm SE & $0.299 \pm 0.016$ & $2.375 \pm 0.0130$ & $2.120 \pm 0.030$ & $5.750 \pm 0.012$ \\
\hline \multirow{3}{*}{ Market raw milk } & -Minimum & 0.058 & 0.850 & 0.025 & 2.400 \\
& -Maximum & 0.883 & 4.050 & 0.150 & 4.650 \\
& -Mean \pm SE & $0.241 \pm 0.037$ & $2.076 \pm 0.163$ & $0.103 \pm 0.006$ & $3.844 \pm 0.088$ \\
\hline \multirow{3}{*}{ Pasteurized milk } & -Minimum & 0.03 & 1.76 & 0.65 & 0.11 \\
& -Maximum & 0.34 & 11.86 & 5.57 & 10.31 \\
& -Mean \pm SE & $0.17 \pm 0.002$ & $4.53 \pm 0.49$ & $1.69 \pm 0.051$ & $3.37 \pm 0.012$ \\
\hline
\end{tabular}

$\overline{\overline{\text { Kafr El-Sheikh Vet. Med. J. Vol. } 1 \text { No. } 1 \text { (2003) }}}$ 
Table(2):Percentages of farm bulk milk, market raw milk and pasteurized milk samples beyond the maximum permissible limits.

\begin{tabular}{|c|c|c|c|c|c|c|c|c|}
\hline \multirow{3}{*}{$\begin{array}{l}\text { Heavy } \\
\text { metals }\end{array}$} & \multirow{3}{*}{$\begin{array}{c}\text { Permissible limits } \\
\begin{array}{c}\text { Country or } \\
\text { organization }\end{array} \\
\end{array}$} & \multicolumn{7}{|c|}{ Beyond the permissible limits } \\
\hline & & \multirow{2}{*}{$\begin{array}{l}\text { Limits } \\
(\mathbf{p p m})\end{array}$} & \multicolumn{2}{|c|}{$\begin{array}{c}\text { Farm bulk } \\
\text { milk }\end{array}$} & \multicolumn{2}{|c|}{$\begin{array}{c}\text { Market raw } \\
\text { milk }\end{array}$} & \multicolumn{2}{|c|}{$\begin{array}{c}\text { Pasteurized } \\
\text { milk }\end{array}$} \\
\hline & & & No/30 & $\%$ & No/30 & $\%$ & No/30 & $\%$ \\
\hline \multirow{5}{*}{ Cadmium } & -Germany & -0.03 & 30 & 100 & 29 & 96.6 & 54 & 90 \\
\hline & -Netherlands & -0.05 & 30 & 100 & 29 & 96.6 & 54 & 90 \\
\hline & -Sweden & -0.02 & 30 & 100 & 29 & 96.6 & 54 & 90 \\
\hline & -Australian & -0.02 & 30 & 100 & 29 & 96.6 & 54 & 90 \\
\hline & -WHO (1980) & -0.02 & 30 & 100 & 29 & 96.6 & 54 & 90 \\
\hline \multirow{5}{*}{ Lead } & -Germany & -0.005 & 30 & 100 & 30 & 100 & 58 & 95 \\
\hline & -Netherlands & -0.005 & 30 & 100 & 30 & 100 & 58 & 95 \\
\hline & -Sweden & -0.01 & 30 & 100 & 30 & 100 & 58 & 95 \\
\hline & -Australian & -0.05 & 30 & 100 & 30 & 100 & 58 & 95 \\
\hline & -WHO (1980) & -0.05 & 30 & 100 & 30 & 100 & 58 & 95 \\
\hline \multirow{3}{*}{ Copper } & -Underwood (1977) & -0.3 & 28 & 93.3 & 28 & 93.3 & 57 & 95 \\
\hline & -Harison (1993) & -0.3 & 28 & 93.3 & 28 & 93.3 & 57 & 95 \\
\hline & -WHO (1980) & -0.3 & 28 & 93.3 & 28 & 93.3 & 57 & 95 \\
\hline \multirow{3}{*}{ Zinc } & -Underwood (1977) & -3.0 & 29 & 96.6 & 28 & 93.3 & 59 & 98.3 \\
\hline & -Eos (1993) & -3.0 & 29 & 96.6 & 28 & 93.3 & 59 & 98.3 \\
\hline & -WHO (1980) & -3.0 & 29 & 96.6 & 28 & 93.3 & 59 & 98.3 \\
\hline
\end{tabular}

Table(3):Correlation coefficient of some heavy metals farm bulk milk and market raw milk and market raw milk and pasteurized milk.

\begin{tabular}{||c||c|c||c|c||}
\hline \hline Metals & \multicolumn{2}{|c||}{ Farm bulk milk and market raw milk } & \multicolumn{2}{c||}{ Market raw milk and pasteurized milk } \\
\hline \hline \multirow{2}{*}{ Cadmium } & $\mathrm{a}$ & $\mathrm{b}$ & $\mathrm{a}$ & $\mathrm{b}$ \\
& $0.128 \pm 0.002$ & $0.233 \pm 0.0140$ & $0.288 \pm 0.014$ & $0.187 \pm 0.011$ \\
\hline \multirow{2}{*}{ Lead } & $\mathrm{a}$ & $\mathrm{b}$ & $\mathrm{a}$ & $\mathrm{b}$ \\
& $0.813 \pm 0.031$ & $2.272 \pm 0.128$ & $2.235 \pm 0.125$ & $2.390 \pm 0.032$ \\
\hline \multirow{2}{*}{ Copper } & $\mathrm{a}$ & $\mathrm{b}$ & $\mathrm{a}$ & $\mathrm{b}$ \\
& $1.729 \pm 0.016$ & $2.119 \pm 0.031$ & $2.121 \pm 0.032$ & $2.133 \pm 0.073$ \\
\hline \multirow{2}{*}{ Zinc } & $\mathrm{a}$ & $\mathrm{b}$ & $\mathrm{a}$ & $\mathrm{b}$ \\
& $4.229 \pm 0.035$ & $5.630 \pm 0.011$ & $4.998 \pm 0.011$ & $4.707 \pm 0.82$ \\
\hline \hline
\end{tabular}

a-b significant difference.

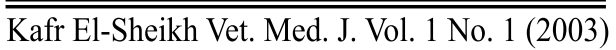




\section{DISCUSSION}

Contamination of milk by heavy metals is one of the major problems confronting public health. Cadmium, lead, copper and zinc receive greater attention than any other heavy metals due to their adverse toxic effects.

Therefore, it has become, important to determine the levels of toxic elements in milk as an essential part of human diet. The dairy animals expose to heavy metals from various sources as a result of modern industerialization. The levels of selected heavy metal concentration in farm bulk milk, market raw milk and pasteurized milk are represented in table (1). The mean levels of cadmium were $0.299 \pm 0.016,0.241 \pm$ 0.037 and $0.17 \pm 0.002 \mathrm{ppm}$ respectively. More or less similar levels were obtained by Fayed (1997), Bayomi et al. (1999), Saad et al. (2001) and Karavoltsos et al., (2002). Lower levels were reported by Kirova (1993), Muller et al. (1993) and Enas and Sharkawy (1999).

According to the permissible limits recorded in different countries and organizations, results in table (2) reveal that 100\%, 96.6\% and $90 \%$ of farm bulk milk, market raw milk and pasteurized milk samples, respectively, contained cadmium above the maximum allowable limits. The sources of food contamination by cadmium were identified by WHO (1989) as phosphate fertilizers and sewage sludge used on agricultural lands, use of cadmium plated utensils and galvanized equipments in food processing and preparation, leachable cadmium in enamal and pottery and cadmium based pigments or sterilizes used food contact.

Cadmium is well recognized as one of the major toxic elements to man and animals. Even low levels may cause in time considerable accumulation in the tissues. It acts as sulfhyryl groups of essential metal enzymes. Higher concentrations are found in hat spots related to human activities and in agricultural lands where high concentrations of phosphate fertilizers and manure are applied (Scoullos et al., 2001). Cadmium toxicity may be manifested by a variety of syndromes and effects including renal dysfunction (Robards and Worsfold,1991 and Elinder and Jarup1996), hypertension (Piperakia1985). Moreover, it may induce prostate cancer, bone changes and slight anemia (WHO,1980). 
Lead is a non essential element for man, with a potential toxic for all biological systems, as it accumulates in human tissues. The mean values of lead concentrations found in farm milk, market raw milk and pasteurized milk samples were $2.375 \pm 0.013,2.076 \pm 0.163$ and $4.53 \pm$ 0.49 respectively (Table 1 ). These findings are parallel to those obtained by Bayomi et al. (1990), Madeha et al. (1994) and Saad et al. (2001), lower levels were detected by Mitrovic et al. (1992) and Muller et al. (1993). High concentrations were recorded by Fayed (1997).

Results showed in table (2) reveal that $100 \%$ of farm bulk milk, market raw milk samples and $95 \%$ of pasteurized milk samples contained lead beyond the maximum permissible limits. Similar results were recorded by Fayed (1997).

Lead is considered one of the most important pollutants in the environment and is distributed widely in different of foods. The major sources of lead in the environment arises from the manufacture and application of alkyl lead fuel additives. Transport and distribution of lead from stationary or mobile source mainly via air. Although larger amounts are probably also discharged into soil and land tends to localize near the points of such discharge(WHO,1977). Lead is an accumulative poison. It has hematological effects as it inhibits the hemoglobin synthesis (Carl, 1991). These effects may lead to anemia and microcythemia. High lead exposure causes encephalopathy resulting in ataxia, coma and convulsions (Ukhun et al., 1990).

On the systems, long term exposures of lead reduces the function of completely damage kidneys, liver and brain tissues. Moreover, it causes constipation, diarrhea,epigastric pain, nusea and indigestion(WHO,1977).

It is obvious from the results present in table (1) that the mean copper concentrations of farm bulk milk, market raw milk and pasteurized milk were $2.120 \pm 0.030,0.103 \pm 0.006$ and $1.69 \pm 0.051$ ppm respectively. 
The results also reveal that the copper levels decreased as the lead increases, these findings are substantiate to those reported by $\boldsymbol{E l}$-Hoshy et al. (1994) and Saad et al., (2001). It has been recorded that some toxic effects of cadmium were related to its copper depleting effects. Where decreasing in copper levels are associated with high cadmium concentration in human and animal organs and tissues (Lamphere et al. 1984).

High levels of copper in raw, pasterurized and UHT milk were detected by Fayed et al. (1997). Normal copper level of copper in milk is 0.3 ppm as milk is a poor source of copper (Underwood, 1977). Results in table (2) indicate that $93 \%, 93 \%$ and $95 \%$ of farm bulk milk, market raw milk and pasteurized milk respectively, exceeded the tolerance limits for human consumption.

A copper is an essential trace element for human and animals, since it acts as a co-factor for several enzymes including cytochrome oxidase and tyrosinase maddition to its role in promoting hematopoiesis.

Copper is a very toxic at higher levels and causes many diseases such as Mediterranean anemia, liver cirrhosis and atrophy and hemochromatosis (Plavic and Casovic, 1988). Excess amounts of copper in food give rise to severe copper intoxication or copper poisoning known as Wilson's disease, because of its affinity for sulfhydryl group, but little is known about the maximum amount which may lead to toxicity. The low levels of copper increase the toxic effects of lead and increase its accumulation in system organs (Evans, 1971).

Szajkowski (1996) pointed our that very low intake of copper was responsible for an inappropriate $\mathrm{Zn}: \mathrm{Cu}$ ratio diet, even in the situation of $\mathrm{Zn}$ deficiency, which is approximately twice as high. Thus increasing the risk of cardiovascular diseases, abnormalities in bone mineralization and anemia in women.

Results present in table (1) reveal that the mean levels of zinc in farm bulk milk, market raw milk and pasteurized milk were $5.750 \pm$ $0.012,3.844 \pm 0.088$ and $3.37 \pm 0.012$ ppm respectively. 


\section{High levels were recorded by Fayed (1997).}

Zinc toxicity which results from inhalation of zinc fumes has been recorded to cause an illness called metal fumes fever (Kenneth, 1987). The normal zinc level in milk is $3 \mathrm{ppm}$. The results recorded in table (2) indicate that $96.6 \%, 93.3 \%$ and $98.3 \%$ of farm bulk milk, market raw milk and pasteurized milk samples respectively, exceeded the maximum tolerance limits for human consumption.

Fayed (1997) recorded that $100 \%$ of raw milk, pasteurized milk and UHT milk contained higher levels of zinc than the permissible limits. Zinc daily intake with the diets was adequate for women but insufficient for men (Skibniewska, 2002).

Statistical analysis results recorded in table (3) point out there was a significant difference $(\mathrm{P}>0.05)$ between farm bulk milk and market raw milk and between market raw milk and pasteurized milk regarding to analyzed heavy metals. This difference may be attributed to the different sources of milk, which depend on circumstance surrounding sources of contamination and dietary intake.

These results are coincident with those observed by Bayomi et al. (1999) and Saad et al. (2001). Contamination of animal feed by heavy metals has been considered the main source of metal residues in meat and milk (Jusklewiez, 1983) and the high levels of lead and cadmium in animal feeds resulted from plant origin due to application of fertilizers containing excessive amount of metals. The addition of considerable amount of processed cotton seed meal to such feeds (Mazurek et al., 1992 and Bayomi et al., 1999).

Another explanation is the bioaccumulation of heavy metals in animal tissues and organs resulting in production of milk containing higher metal levels (Bluthgen et al., 1984 and Antoniou et al., 1989).

In conclusion, the results of this investigation reveal that the examined milk samples proved to contain heavy metal beyond the permissible limits set by all organizations for human consumption, which 
may constitute a possible public health hazards. Therefore, monitoring of heavy metals in different types of milk in Sharkia Governorate should be done to deal with public health aspects and effects should be directed to minimize the heavy metals contamination of milk.

\section{REFERENCES}

- Antoniou, V.; Tosoukali-Papadopoulou,H.;Ipivatimos, P. and Nthanael, B. (1989): Cadmium concentration in beef consumable tissue in relation to age of animal and area of their breeding. Bull. Environ. Contam. Toxicol., 43: 915-919.

- Bayomi, A.M.; Hassan, A.M.; Hussein, M.M. and Saleh, R.S. (1999): Pollution of water and animal feed milk with some heavy metals and their implication in raw buffalo milk. 5th Scientific Conf., Egyptian Society for Cattle Diseases. Fac. Vet. Med., Assiut Univ., Egypt.

- Bluthgen,A.;Heaschen,W.and Nijhuis,H.(1984):Residues and contaminat- ion in milk and milk products.Royal Society and Chemistry No.49:206-635.

- Carl,M.(1991):Heavy metals and other trace elements monographn residues and contamination in milk and milk products. Chapter 6. International Dairy Federation, Bulguim.

- Crosby, N. T. (1977): Determination of metabolic foods. A review j. the Analyst. 102 (12): 1213.

- Crossman,G.(1981):Further ung Sweise. Arch. Lebensmittelhyg.32: 87-89.

- El-Hoshy, S.M.; Draz, A.A. and Samaha, H.A. (1994): Influence of lead and copper as water on their level in produced milk. 6th Sci. Cong. Fac. Vet. Med. Assiut Univ. Egypt.

- Elinder, C.G. and Jarup, L. (1996): Cadmium exposure and health risks recent findings. Ambio. 25: 370-373.

- Enas, E.P. and Sharkawy, A.A. (1999): Estimation of some heavy metals in bovine milk in Assiut Governorate. Assiut Vet. Med. J., 41: 153-169.

- Evans, C.W. (1971): Biological function of copper. Chemistry. 44: 
$10-13$.

- $\boldsymbol{F A O}$ (1992): International Conference on Nutrional major issues for "arough improved food

- Fayed, A.H. (1997): Pollution of raw milk with some heavy metals. M.V.Sc., Thesis, Fac. Vet. Med., Alex. Univ., Egypt.

- Hankinson, D.J. (1975): Potential source of copper contamination of farm milk supplies measured by Atomic Absorption Spectrophotometer. J. Dairy Sci., 58: 326.

- Jusklewiez, T. (1983): Residues of xenobiotic in animals, milk and environment in the light of 13 years surveillance in: Veterinary Pharmacology. Edited by V. Ruckebluch, P.L. Touifen and D.Kortiz (1980), MIP press limited, Boston USA. pp. 641-645.

- Karavoltsos, S.; Sakellari, A.; Dimopoulos, M.; Dasenakis,M.and Scoullos T. (2002): Cadmium content in food stuffs from the Greek market. Food Additives and Contaminant. 19 (10): 954-962.

- Kenneth, H.F. (1987): Disturbance in trace elements metabolism. In Braunwald,E.,Esselkocher, KL.;Petersdorf, R.G.;Wilson, J.D.; Martin, J.B.; Fanci,A.S.Eds.Horrison's principle of internal medicine.11th Ed.,New York, McGraw Hill Book Co., 481-21.

- Kirova, A. (1993): Cadmium content in milk from an industrially region. Khranitelra-Promishlenost-Sofia. 42: 26-27.

- Lamphere, D.N.; Dorn, C.R.;Reddg,C.S.and Meyer, A.W. (1984): Reduced cadmium body burden in cadmium exposed calves fed supplement zinc. Environ. Res., 33: 119-122.

- Madeha, A.A.; Abdel-Kader, M.A. and Tarek, L.Y. (1994): Lead, cadmium and mercury in milk products. Assiut Vet. Med. J., 30: 139-144.

- Mahaffey, K. R. (1977): Mineral concentration in animals tissue;certain aspects of FAD's regulatory role. J. Animal Sci., 44: 509.

- Mazurek, w.; Mazurk, M.and Zawadzka-Ostrowska, W.(1992):

$\overline{\text { Kafr El-Sheikh Vet. Med. J. Vol. } 1 \text { No. } 1 \text { (2003) }}$ 
Monitoring studies on lead, cadmium, mercury content in polish fruits and cereals. 3rd World Congress, Foodborne Infection and Intoxication, 16-19 June.

- Mitrovic, R.; Zivkovic, D.; Nikic, D.; Stajanavic, D.; Obradavic, V.; Golubovic, $R$. and Todorovic, A.(1992): Lead, cadmium in human, cow and adapted milks, Harana-I-Ishrana 33 (314) $153-$ 155.

- Muller, M.; Anke, M.; Hartman, E. and Arnhold, W. (1993): Lead and cadmium contamination of milk and various milk products. Qualitiate Hygiene Lebensmitteln in Produktion and Verabeitung, 417-420.

- Piperakia, E.A. (1985): Determination of cadmium in blood by flamless utomic absorption spectroscopy. Chemica Chemica, n.s., 14: 587-60.

- Plavic, M. and Casovic, B. (1988): On interaction of copper with surface active material in natural waters. Repp. Comm. Int. Mer. Medit. 31: 2-9.

- Robards, K. and Worspold, P. (1991): Cadmium Toxicology and Analysis a review, Anelyst. 116: 549-562.

- Saad, A.H.; El-Kosi, O.H. and Abdel-Hakiem E.H. (2001): Surveillance of some heavy metals in raw milk. Cong. Of Food Hygiene and Human Health. Fac. Vet. Med., Assiut Univ., Egypt.

- Scoullos, M.; Voskeman,G.;Thorston,L. and Makuch,Z.(2001): Cadmium, mercury, cadmium-lead. Handbook for sustainable Heavy Metals Policy and Regulation, edited by M.S. Coullos (Durdreeht Klumer) pp. 71-72.

- Skibneiwska, N.A. (2002): Estimation of iron, copper, zinc and many a nase intake from duplicated diets provided by hospitals in Poland Food additives and contamination. 19 (10): 969-973.

- Szajkowski, Z. (1996): Studies of the content and natural relations between certain mineral components in daily food rations of selected populations in the Wielkopolska Region. Part II. Content and interrelations between $\mathrm{Zn}$ and $\mathrm{Cu}$. Zywienic. Colowieka Metabolism. 23: 66-76. 
- Ukhun, M.E.; Nwazato, J. and Nkwocha, F.O. (1990): Levels of toxic mineral elements in selected food marketed in Nigeria. Bull. Contam. toxicol., 44: 325-330.

- Underwood, E.J. (1977): Trace Elements in Human and Animal. Nutrition, 4th Ed., Academic press. Inc., London.

- WHO (1977): Environmental Health criteria. No. 3 Lead. World Health Organization, WHO. Geneva pp. 160.

- WHO (1980): Technical Report Series Recommended Health Based Limits in Occupational Exposure to Heavy Metals Report of WHO Study Group. Technical Report Series No. 647.

- WHO (1989):Evaluation of certain food additives and

TAO, WHO Expert

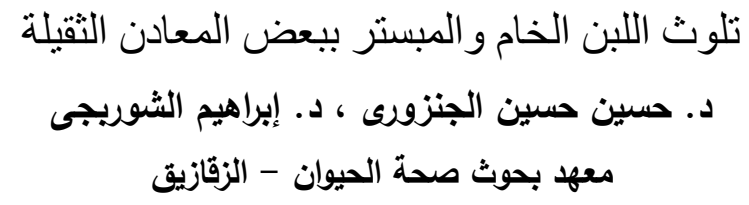

تعتبر العناصر الثقيلة من أهم الملوثات الكيميائية للألبان والتىى لها آثار ضارة على صحهة صلى

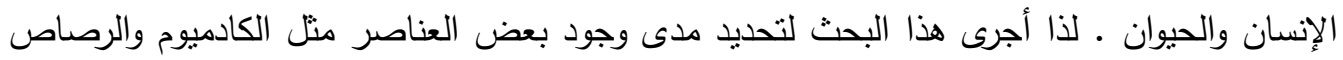

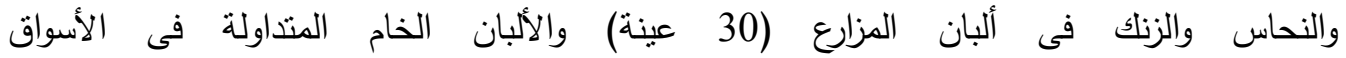
(30 عينة) واللبن المبستر (40 عينة)

وقد أثتتت النتائج أن متوسط تركيز تلك العناصر في ألبان المزارع كانت 0.299 ـ 0.016 ، 2.37 土 0.13 و 2.12 土 0.03 و 5.75 × 0.012 جزء فى المليون على التوالى.

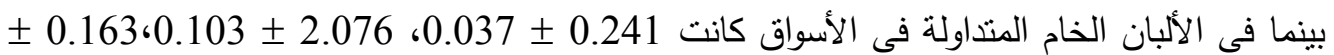
0.006 ، 3.844 × 0.088 جزء فى المليون على التوالى. وفى اللبن المبستر كانت 0.17 ـ 0.002 ، 4.53 وقد أظهرت مقارنة عينات ألبان المزارع والألبان الخام النتداولة فى الأسواق واللين المبستر

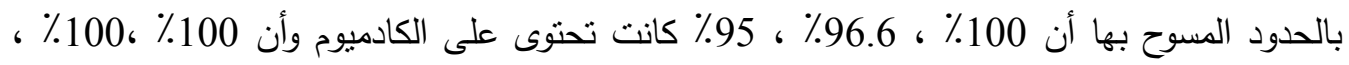
95\% كانت تحتوى على الرصاص وأن 93.3\% ، 93.3\% ، 95\% كانت تحتوى على النحاس وأن

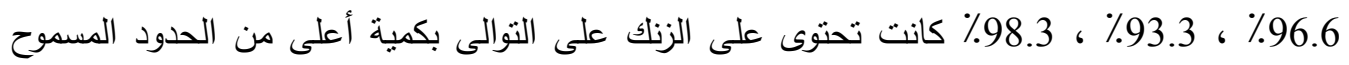


بها. وقد أوضحت نتائج التحليل الاحصائى للمعادن الثقبلة التى نم فحصها بأن هناك فرق معنوى بين

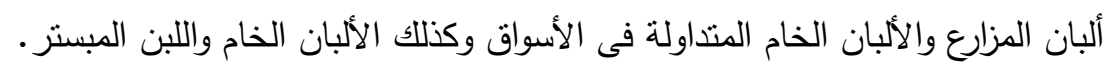

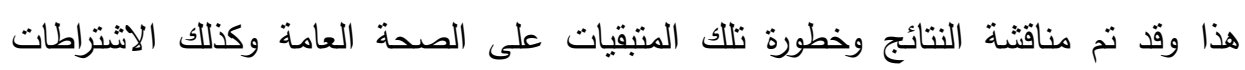

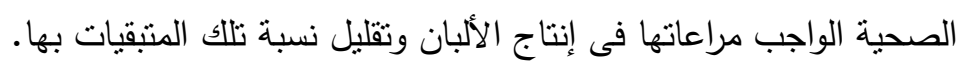

